\title{
FEDERAL VERSUS KESATUAN: SEBUAH PROSES PENCARIAN TERHADAP BENTUK NEGARA DALAM MEWUJUDKAN OTONOMI DAERAH
}

\author{
Oleh : \\ Indah Sari, SH, M.Si \\ Dosen Tetap Fakultas Hukum Universitas Suryadarma Jakarta. \\ Aktif di Lembaga Konsultasi dan Bantuan Hukum (LKBH) Fakultas Hukum Universitas Suryadarma dan \\ Anggota Assosiasi Dosen Seluruh Indonesia (ADI). \\ Email : (Indah.alrif@gmail.com)
}

\begin{abstract}
Abstrak:
Sebagian besar negara di dunia memilih bentuk negara Federal atau Kesatuan dalam menyelenggarakan pemerintahan. Pemilihan bentuk negara ini didasarkan kemauan politik, sosial budaya serta sejarah dari sebuah negara. Masing-masing bentuk negara ini mempunyai kelebihan dan kelemahan. Negara Kesatuan menitikberatkan penyelenggaraan pemerintahan pada pemerintahan pusat dan daerah-daerah di propinsi tidak mempunyai otonomi yang luas dalam mengurus daerahnya. Lain halnya dengan Negara Federal dimana kedudukan Negara Federal dan Negara Bagian sederajat. Negara Bagian diberikan otonomi yang seluas-luasnya untuk mengurus daerah mereka. Sehingga hal ini sangat menarik bagi penulis untuk mengkaji lebih dalam, bentuk negara yang bagaimana yang bisa menjamin terlaksananya otonomi daerah dilihat dalam konteks sejarah perjalanan Bangsa Indonesia.
\end{abstract}

\section{PENGANTAR}

Wacana perdebatan kenegaraaan Indonesia sering diwarnai perdebatan dengan munculnya konsep negara federal yang merupakan solusi terbaik dalam menghadapi tuntutan masyarakat di daerah terhadap pusat, yang disebabkan adanya kesenjangan antara pusat dan daerah dalam masalah perimbangan keuangan, pembangunan, pendidikan dan disamping itu juga otonomi yang dijanjikan oleh Undang-Undang belum terealisir sampai ke daerah, sehingga pemerintah pusat gagal menciptakan otonomi daerah.

Dimana otonomi daerah itu sendiri diartikan adalah penyerahan urusan pemerintah kepada pemerintah daerah yang bersifat operasional dalam rangka sistem birokrasi pemerintahan. Tujuan dari otonomi adalah mencapai efektivitas dan efisiensi dalam pelayanan kepada masyarakat, menumbuhkembangkan daerah dalam berbagai bidang, meningkatkan pelayanan kepada masyarakat, menumbuhkan kemandirian daerah 
dan meningkatkan daya saing daerah dalam proses pertumbuhan. ${ }^{1}$

Apakah Negara kesatuan atau Negara Federal yang bisa menjamin terlaksananya otonomi daerah? Marilah kita melihat lebih dahulu perbedaan antara Negara Kesatuan dengan Negara Federal. Sebenarnya apakah yang di maksud dengan Negara Kesatuan dan Negara Federal tersebut? Dalam Negara Kesatuan bahwa kedaulatannya tidak terbagi, atau dengan kata lain kekuasaan pemerintah pusat tidak dibatasi, karena konstitusi negara kesatuan tidak mengakui badan legislatif lain selain dari badan legislatif pusat sedangkan dalam Negara Federal bahwa kekuasaan dibagi sedemikian rupa sehingga pemerintah federal dan pemerintah negara bagian dalam bidang-bidang tertentu adalah bebas satu sama lain. ${ }^{2}$ Pengertian dari Negara Kesatuan yang lain adalah yang disebut dengan Negara Kesatuan apabila kekuasaan Pemerintah Pusat dengan Pemerintah Daerah tidak sama dan tidak sederajat. Kekuasaan pemerintah pusat merupakan kekuasaan yang menonjol dalam Negara, dan tidak ada saingan dari badan legislatif pusat dalam membentuk undang-undang sedangkan yang disebut dengan Negara Federal jika kekuasaan itu di bagi antara Pusat dan Daerah / Bagian dalam negara itu sedemikian rupa sehingga masing-masing daerah / bagian dari negara itu bebas dari campur tangan satu dengan yang

${ }^{1}$ Haw.Widjaja, Penyelenggaraan Otonomi di Indonesia, (2013), Rajawali Press, Jakarta, hlm.17.

${ }^{2}$ Miriam Budiardjo, Dasar-Dasar Ilmu Politik, (2008), Gramedia Pustaka Utama, Jakarta, hlm, 269-271. lainnya dan hubungannya sendirisendiri terhadap Pusat. ${ }^{3}$

Sekarang mari kita kaitkan antara bentuk negara dengan pelaksanaan otonomi daerah. Titik berat otonomi yang diisyaratkan oleh beberapa Undang - Undang otonomi daerah yang pernah berlaku di Indonesia hanyalah lip service belaka. Bahwa sepanjang Indonesia merdeka sejak tahun 1945 -2014 telah diberlakukan delapan Undang-Undang otonomi daerah. Adapun Undang-undang otonomi daerah yang pernah berlaku di Indonesia tersebut adalah: ${ }^{4}$

- Undang-Undang RI Nomor 1 tahun 1945

- Undang-Undang RI Nomor 22 tahun 1948

- Undang-Undang RI Nomor 1 tahun 1957

- Undang-Undang RI Nomor 18 tahun 1965

- Undang-Undang RI Nomor 5 tahun 1974

- Undang-Undang RI Nomor 22 tahun 1999

- Undang-Undang RI Nomor 32 tahun 2004

- Undang-Undang RI nomor 23 tahun 2014.

Rasa ketidakadilan antara pemerintah pusat dan pemerintah daerah yang ditimbulkan dari praktek kekuasaan pemerintah lebih-lebih lagi ketika semasa Orde Baru yang telah menciptakan penyelenggaraan pemerintahan yang sentralistik dan otoritarianistik yang menyebabkan

\footnotetext{
${ }^{3}$ Baca lebih lanjut Moh. Kusnardi dan Bintan Saragih, Ilmu Negara, (2008), Gaya Media Pratama, Jakarta, hlm, 207-209.

4 Undang-Undang mengenai Otonomi Daerah yang pernah berlaku di Indonesia serta perbandinganperbandingannya, Blogspot.com, 2014
} 
daerah tidak mandiri dan sangat tergantung pada pemerintahan pusat.

Permasalahan-permasalahan diatas tentu menjadi tantangan bagi Negara Indonesia untuk berusaha menemukan solusi yang tepat dalam menciptakan keseimbangan antara pusat dan daerah dan bagaimana menghubungkan antara keduanya dengan cara yang akan menimbulkan pembangunan yang lebih efektif lagi.

Sehingga beberapa kalangan menemukan solusi dalam penyelenggaraan negara dalam bentuk Negara Federal. Yang menjadi pertanyaan selanjutnya adalah apakah dengan memunculkan konsep Negara Federal akan dapat menyelesaikan permasalahan yang terjadi di Indonesia khususnya dalam penyelenggaraan pemerintahan negara?

Oleh karena itu sangat menarik bagi penulis untuk mengkaji permasalahan ini lebih dalam lagi. Disini penulis mencoba untuk memulai perbincangan dari konsep negara dan mencoba mengkaitkan dengan permasalahan yang terjadi di Indonesia khususnya yang berkaitan dengan otonomi daerah sampai pada akhirnya solusi apa yang terbaik bagi Indonesia.

\section{PERMASALAHAN}

1. Bagaimakah perbedaan antara konsep Negara Kesatuan dan Negara Federal?

2. Apakah konsep Negara Federal atau Negara Kesatuan yang dapat menjamin terlaksananya Otonomi Daerah?

\section{PEMBAHASAN}

\section{A. Negara Kesatuan}

Dalam model Negara Kesatuan, asumsi dasarnya berbeda secara diametric dari Negara Federal. Formasi Negara Kesatuan dideklarasikan saat kemerdekaan oleh para pendiri negara dengan mengklaim seluruh wilayahnya sebagai bagian dari satu negara. Tidak ada kesepakatan para penguasa daerah, apalagi negaranegara, karena diasumsikan bahwa semua wilayah yang termasuk di wilayahnya bukanlah bagian-bagian wilayah yang bersifat independen.

Dengan dasar itu, maka negara membentuk daerah-daerah atau wilayah - wilayah yang kemudian diberi kekuasaan atau kewenangan oleh Pemerintah Pusat untuk mengurusi berbagai kepentingan masyarakatnya. ${ }^{5} \mathrm{Di}$ Indonesia sendiri daerah-daerah tersebut dinamakan provinsi. Provinsi-provinsi ini kemudian diberi otonomi, diberi kedaulatan untuk mengurus rumah tangganya sendiri untuk hal-hal yang sudah ditentukan oleh pemerintah pusat. Kedaulatan atau yang namanya otonomi di provinsi ini hanyalah otonomi yang ditentukan. ${ }^{6}$

Disini diasumsikan bahwa negaralah yang menjadi sumber kekuasaan. Kekuasaan daerah pada dasarnya adalah kekuasaan

5 Andi A. Mallarangeng \& M. Ryaas Rasyid, Otonomi dan Federalisme Dalam Buku Federalisme Untuk Indonesia, (1999), Jakarta : Penerbit Kompas, hlm. 18.

$6 \quad$ Ibid., hlm. 25 
pusat yang disentralisasikan, dan selanjutnya terbentuklah daerahdaerah otonom. Jadi didalam negara kesatuan sangat jelas otonomi daerah adalah wujud dari kekuasaan. ${ }^{7}$

Di Indonesia sendiri konsep Negara Kesatuan tertuang dalam Undang-Undang Dasar 1945 Pasal 1 ayat (1), dimana disana dinyatakan secara tegas bahwa Indonesia Negara Kesatuan yang berbentuk Republik. Penjelasan lebih lanjut tentang prinsip Negara Kesatuan dijelaskan bahwa yang memegang tampuk kekuasaan tertinggi atas segenap urusan negara ialah pemerintahan pusat tanpa adanya suatu delegasi atau pelimpahan kekuasaan kepada pemerintahan daerah (local government) ${ }^{8}$.

Di dalam Negara Kesatuan juga terdapat asas bahwa segenap urusan-urusan negara tidak dibagi antara Pemerintahan Pusat (Central Government) dengan Pemerintahan Daerah (Local Government) sedemikian rupa, sehingga urusan-urusan negara dalam Negara Kesatuan tetap merupakan suatu kebulatan dan bahwa Pemegang Kekuasaan Tertinggi di Negara ialah Pemerintahan Pusat. Di samping itu juga tanggung jawab pelaksanaan tugas-tugas pemerintahan pada dasarnya tetap berada di tangan pemerintahan pusat. Akan tetapi karena sistem pemerintahan

Ibid., hlm. 18

8 M. Solly Lubis, Pergeseran Garis Politik dan Perundang-Undangan Mengenai Pemerintah Daerah. (1983), Bandung : Alumni, hlm. 8
Indonesia yang menganut asas

Negara Kesatuan yang disentralisasikan, maka ada tugastugas tertentu yang oleh pemerintah pusat diserahkan sepenuhnya kepada daerah untuk diatur dan diurus sendiri, sehingga menimbulkan hubungan timbal balik yang melahirkan adanya hubungan kewenangan dan pengawasan.

\section{B. Negara Federasi}

Untuk mencapai suatu pengertian apa yang dimaksud dengan Negara Federal alangkah lebih baik kita membahas terlebih dahulu bagaimanakah proses pembentukan Negara Federal.

Dilihat dari asal-usulnya, kata "federasi" berasal dari bahasa latin, feodus yang artinya Liga. Liga Negara - negara kota yang otonom pada zaman Yunani kuno dapat dipandang sebagai Negara Federal yang mula-mula. Bentuk modern pemerintahan federal berasal dari pengalaman konstitusional Amerika Serikat. Dapat dikatakan bahwa pemerintahan federal merupakan salah satu sumbangan sejarah ketatanegaraan Amerika Serikat terhadap dunia modern. ${ }^{9}$

Model Negara Federal berangkat dari suatu asumsi dasar bahwa ia

\footnotetext{
9 Lihat Joseph Rudolph., Jr "Federation". Dalam International Encyclopedia of Government and Politics. Vol. 1 yang diedit Frank N. Magill. Singapura : Toppan 1996, hlm. 467. Lihat dalam Syamsul Rizal Panggabean. Komparasi Konsep Bentuk Negara dan Negara Federasi Dalam Pembangunan Politik di Indonesia. Yang diselenggarakan atas kerjasama FH-UGM KRHN.LBKHI dan Augustinus Hutajulu, SH, CN \& Associate. 31 Oktober 1998, hlm. 3.
} 
dibentuk oleh sejumlah negara atau wilayah yang independen, yang sejak awal memiliki kedaulatan atau semacam kedaulatan pada dirinya masingmasing. Negara-negara atau wilayah-wilayah itu yang kemudian bersepakat membentuk sebuah federal. Negara dan wilayah pendiri federasi itu kemudian berganti status menjadi negara bagian atau wilayah administrasi dengan nama tertentu dalam lingkungan federal.

Dengan kata lain, negara atau wilayah yang menjadi anggota federasi itulah yang pada dasarnya memiliki semua kekuasaan yang kemudian diserahkan sebagian kepada pemerintahan federal. Biasanya, pemerintahan federal diberi kekuasaan penuh dibidang moneter, pertahanan, peradilan, dan hubungan luar negeri. Kekuasaan lainnya cenderung tetap dipertahankan oleh negara bagian atau wilayah administrasi. Kekuasaan bagian biasanya sangat menonjol dalam urusanurusan domestik, seperti pendidikan, kesehatan, kesejahteraan sosial, dan keamanan masyarakat (kepolisian)

Ringkasnya, pembentukan suatu negara federasi melalui dua tahap, yaitu tahap pengakuan atas keberadaan negara-negara dan wilayah independen dan tahap kedua adalah kesepakatan mereka membentuk negara federal. Ini bisa dilihat dalam sistem federalisme di Amerika Serikat dan Malaysia. ${ }^{10}$

Jadi melihat dari pembentukan Negara Federal tersebut kita dapat mengambil suatu pendefinisian bahwa Negara Federal adalah negara yang tersusun dari beberapa negara yang semula berdiri sendiri kemudian negara-negara mengadakan ikatan kerjasama yang efektif, tetapi disamping itu, negara-negara tersebut masih ingin mempunyai wewenangwewenang yang dapat diurus sendiri. Jadi, disini tidaklah semua urusan diserahkan kepada pemerintah gabungannya atau pemerintah federal, tetapi masih ada beberapa urusan tertentu yang tetap diurus sendiri. Biasanya urusan-urusan yang diserahkan oleh pemerintah negara-negara bagian kepada pemerintahan federal adalah urusan-urusan yang menyangkut kepentingan semua negara-negara bagian tersebut misalnya urusan moneter, pertahanan, peradilan dan hubungan luar negeri.

Dalam Negara Serikat atau Federal kekuasaan negara terbagi antara Negara Bagian dan Pemerintah Federal. Kekuasaan asli ada pada Negara Bagian sebagai badan hukum negara yang bersifat sendiri-sendiri yang secara bersama-sama membentuk pemerintahan federal dengan batas-batas kekuasaan yang disepakati bersama oleh negaranegara bagian dalam Konstitusi

${ }^{10}$ Andi A. Mallarangeng \& M. Ryass Rasyid. Op.Cit, hlm. 17-18 
Federal. Urusan pertahanan, keuangan, dan hubungan luar negeri di negara serikat/federal selalu ditentukan sebagai urusan pemerintahan federal, sehingga dalam praktek Pemerintahan Federal cendrung sangat kuat kedudukannya. Dalam pengalaman abad ke-20 di berbagai negara serikat / federal timbul kecendrungan terjadinya sentralisasi pengelolaan kekuasaan negara ke tangan pemerintah federal. ${ }^{11}$

Adapun beberapa segi positif dari konsep Negara Federal antara lain, pertama federalisme adalah strategi yang paling tepat untuk membuka kekuasaan yang pada masa lalu amat tertutup. Masyarakat pada umumnya mendambakan keterbukaan.

Banyak mekanisme dan lembaga demokrasi yang dikembangkan dalam rangka membuka kekuasaan itu, contohnya adalah perwakilan politik. Kedua, federalisme dipandang sebagai usaha menyeimbangkan kekuasan budaya daerah, suku atau etnis yang ada dalam suatu negara.

Ketiga, didalam sistem federal, ada unsur-unsur yang dapat membantu menghindari kecenderungan kearah intensifikasi ketimpangan ekonomi dan konflik-konflik

${ }^{11}$ Jimly Asshiddiqie, Pokok-Pokok Hukum Tata Negara Indonesia Pasca Reformasi, (2007), Buana Ilmu Populer, Jakarta, hlm. 282-283

$$
\begin{aligned}
& \text { politik dan budaya yang } \\
& \text { menyertainya. }{ }^{12}
\end{aligned}
$$

Tetapi konsep negara federasi ini juga mengandung sisi negatif seperti adanya persepsi tentang Negara Federal yang identik dengan anti persatuan dan kesatuan bangsa, disamping itu juga adanya kekhawatiran bahwa negara bagian akan berubah menjadi negara suku. Menurut Sri Soemantri bentuk Negara Federal memiliki kelemahan mendasar, yaitu memberi kesempatan kesemua provinsi sebagai daerah otonom untuk menikmati hasil sumber daya alam daerahnya tanpa perlindungan Undang-Undang Perimbangan Keuangan. ${ }^{13}$

Dengan mengkomparasikan dua konsep bentuk negara seperti diatas ada perbedaan yang mendapat antara keduanya yaitu kalau negara federal yang memberikan kekuasaan adalah negara bagian, sedangkan dalam Negara Kesatuan Pusat yang memberikan kekuasaan kepada daerah dalam bentuk disentralisasi atau otonomi.

\section{Permasalahan yang terjadi di Indonesia}

\section{Zaman Hindia Belanda}

12 Syamsul Rizal Panggabean. "Komparasi Konsep Bentuk Negara Kesatuan dan Negara Federasi Dalam Pembangunan Politik di Indonesia. "Makalah disampaikan pada Seminar Nasional Membangun Indonesia Baru: Suatu Pendekatan Konstitusional dan politik. Diselenggarakan atas kerjasama $\mathrm{FH}$ UGM, KHRN, LBKHI, dan Augustinus Hutajulu, SH, CN \& Associate, Yogyakarta. 31 Oktober 1998, hlm. 6-10

${ }^{13}$ Kompas, 31 Agustus 1998. 
Pemerintah Hindia Belanda di wilayah nusantara menemukan bentuknya yang bersifat sentralistik sejak tahun 1905. Bentuk pemerintahan ini telah secara final mematikan independensi daerah-daerah, baik dalam konteks kehadiran raja - raja lokal yang sangat tergantung pada pemerintahan Belanda, mulai dari gaji yang mereka terima sampai kepada keputusan - keputusan yang mereka ambil maupun dalam konteks administrasi pemerintahan mereka.

Format ini yang terpelihara hingga kita memproklamasikan

kemerdekaan. Dalam periode antara 1905 hingga 1945, pulau-pulau nusantara telah merupakan satu kesatuan politik dibawah kekuasaan Belanda, dan sebentar dibawah kedudukan Jepang. Begitu kuatnya hasil penyatuan pulau-pulau nusantara itu, sehingga para pemuda Indonesia yang mendeklarasikan Sumpah Pemuda tahun 1928 pun menyakini sebagai Satu Tanah Air, atau Satu Nusa yang tidak terbagi-bagi. Pidato Bung Karno dalam rapat Badan Penyelidik Usaha-usaha Persiapan Kemerdekaan Indonesia (BPUPKI) juga menjelaskan keyakinan ini. Ringkasnya, semua pendiri negara pada waktu itu sepakat untuk mendirikan sebuah negara kesatuan yang bukan merupakan penjumlahan dari beberapa negara bagian.

Wacana para pendiri negara itupun diyakini oleh sebagian besar rakyat Indonesia sebagai acuan nilai dalam upaya membangun semangat kebangsaan. Maka, strategi Belanda untuk mendelegitimasi negara hasil proklamasi 17 Agustus 1945 itu adalah dengan mendorong lahirnya negaranegara diluar formasi UUD $1945 .{ }^{14}$

\section{Republik Indonesia Serikat} (RIS)

Pemerintah Belanda yang
berusaha menegakkan
kembali kekuasaannya di
Indonesia, menciptakan
negara-negara bagian dan
satuan-satuan kenegaraan
yang dimaksud untuk
melumpuhkan status Republik Indonesia yang dibentuk dengan Proklamasi 17 Agustus 1945 sebagai Negara Nasional, serta untuk memecah belah rakyat Indonesia (politic devide et empira). Usaha Pemerintah Belanda itu menghasilkan pembentukan Negara Republik Indonesia Serikat pada tanggal 27 Desember 1949 yang terdiri dari 16 daerah bagian, yaitu tujuh negara bagian (Negara

${ }^{14}$ Andi A Mallarangeng \& M.Ryaas Rasyid, 1999. Op. Cit, hlm. 19-20. 
Republik Indonesia, Yogya) dengan wilayah menurut status quo yang tercantum dalam persetujuan Renville tanggal 17 Januari 1948, Indonesia Timur, Pasundan, Jawa Timur, Madura, Sumatera Timur dan Sumatera selatan dan sembilan satuan kenegaraan yang berdiri sendiri, yaitu Jawa Tengah, Bangka, Belitung, Riau, Kalimantan Barat, dan Kalimantan Timur. ${ }^{15}$

Dengan berdirinya Negara Indonesia Serikat ini merupakan hasil jerih payah Belanda untuk menunjukkan kepada dunia bahwa republik yang kita proklamirkan pada tanggal 17 Agustus 1945 sudah runtuh. Ia tidak lagi memiliki kedaulatan. Ketika Belanda berkesempatan memainkan kartunya dalam perundingan-perundingan Konferensi Meja Bundar (KMB) untuk menyerahkan kedaulatan kepada pemerintah bekas jajahan ini, mereka bersikukuh mengakui keberadaan negara-negara itu sebagai satuan-satuan politik yang independen. Karena itu hasilnya adalah pembentukan Negara Republik Indonesia Serikat. Negara proklamasi telah direduksi menjadi salah satu negara dalam serikat itu. Inilah bentuk pemerintah

${ }^{15}$ Harun Al Rasyid, Federalisme Mungkinkah bagi Indonesia dalam buku Fedelisme Untuk Indonesia. (1999), Jakarta : Penerbit Kompas, hlm. 5-6 federal yang pernah kita miliki. Akan tetapi sejarah membuktikan bahwa umur dari proyek federalisme in sangat pendek. Ia ditolak justru oleh para pemuda pejuang di negara-negara bagian bentukan Belanda tersebut. Kita kemudian sepakat kembali kedalam bentuk Negara Kesatuan. ${ }^{16}$

Munculnya pemerintahan federal pada masa itu semata-mata memang rekayasa dari Belanda yang memang tidak menginginkan Indonesia menggunakan bentuk Negara Kesatuan. Dan yang pasti pada saat itu munculnya konsep federalisme bukanlah dari bangsa Indonesia sendiri tetapi dengan pembentukan Negara Indonesia Serikat (RIS) merupakan usaha Belanda untuk memecah belah rakyat Indonesia kembali.

\section{Ketegangan Pusat - Daerah Semasa Orde Lama}

Semasa pemerinthan Orde Lama terdapat empat pilar penjelasan penyebab munculnya pemberontakan daerah, Amal (1992). ${ }^{17}$

Pertama, pemberontakan daerah di luar Jawa dilatarbelakangi oleh

\footnotetext{
${ }^{16}$ Andi A. Mallarangeng \& . Ryaas Rasyid, Op.Cit, hlm. 20-21

17 Ichlasul Amal Regional and Central Government in Indonesia Politics : West Sumatra And South Sulawesi 1949 - 1979, (1992), Yogyakarta Gajah Mada University Press
} 
ketimpangan struktur ekonomi yang mencolok antara Jawa dan luar Jawa. Kekecewaan luar Jawa di bidang ekonomi ini diperparah oleh kondisi politik yang dimonopoli oleh Jawa yang menipiskan harapan luar Jawa untuk mempengaruhi proses politik nasional. Partai terbesar dalam Pemilu 1955 adalah PNI berbasis Jawa juga NU dan PKI berbasis Jawa dan hanya ada satu partai luar Jawa yang berpengaruh yaitu Masyumi.

Kedua, pemberontakan masa Orde Lama di dorong oleh kekecewaan tehadap sistem pemerintahan yang sentralistik yang tidak memberikan raung yang memadai terhadap otonomi daerah. Ketika pemerintah pusat mulai berusaha untuk mengembangkan otonomi daerah pada tahun 1957 dengan lahirnya UU No. 1/1957, ketika itu juga kekecewaan daerah memuncak, dan respon pemerintah pusat ini sudah terlambat.

Ketiga, pengorganisasian militer yang berkonsidensi dengan pengorganisasian sipil dan menjadi satu kesatuan dengan polarisasi kultur. Profesionalisasi dan rasionalisasi organisasi militer yang dilakukan oleh militer pusat didikan Eropa telah merugikan para militer daerah yang berpendidikan rendah.

Disini

pemberontakan daerah di dorong oleh konflik internal militer yang kemudian menyatu dengan kepemimpinan sipil dan solidaritas cultural.

Keempat, munculnya perdebatan tentang dasar negara dengan adanya penolakan terhadap Pancasila sebagai dasar negara. Sejak awal 1950-an pertentangan antara para nasionalis dibawah Soekarno yang secara tegas mendukung Pancasila dengan Masyumi yang mendukung Islam sebagai dasar negara semakin tajam. Pertentangan antara nasionalis yang menjadi aktor dominan di pemerintahan pusat ini dengan Masyumi dengan cepat menjadi perseteruan antara pusat (Jawa) dan luar Jawa sesuai dengan peta geografis basis sosial mereka.

\section{Ketegangan Pusat - Daerah Semasa Orde Baru}

Semasa Orde Baru konsep Negara Kesatuan mengalami berbagai distorsi. Dimana pada masa pemerintahan Soeharto kekuasaan hanya ada pada satu tangan. Dimana Lembaga Kepresidenan memegang tampuk kekuasaan tertinggi, ini sebagai konsekuensi logis dari asas "the concentration of power and responsibility upon the president" sehingga 
sentralisasi kekuasaan pada periode ini sangat dominan dan disamping itu juga diadakannya uniformitas struktur pemerintahan. Penyeragaman dan sentralisasi diberlakukan terhadap infra struktur tingkat lokal. Sentralisasi politik dan ekonomi tersebut menyebabkan otonomi daerah dikebiri dan menimbulkan politik otoritarian. Pengalaman traumatik Orde Lama yang rawan terhadap bahaya integrasi nasional menyebabkan Pemerintahan Orde baru menjalankan otonomi daerah dengan setengah hati dan jauh dari apa yang dicita-citakan, otonomi daerah dijadikan sarana untuk menciptakan legitimasi bagi Pemerintah Pusat untuk bertindak secara otoriter.

Elit pemerintahan lokal hanyalah sekedar kepanjangan tangan Pemerintah Pusat di daerah yang diberi kekuasaan besar untuk melakukan maneuver politik untuk menunjukkan pengabdiannya ke pusat. Kebijakan ini bisa dilihat dalam substansi UU No. 5 Tahun 1974 tentang Pokokpokok Pemerintahan di Daerah. Dengan kata lain dalam Era Orde baru ini telah terjadi proses negaraisasi (state formation) secara luar biasa dan berupaya menisbikan eksistensi politik lokal yang telah lama berakar di masyarakat (Schiller 1996). Hal ini semakin efektif melalui keterlibatan militer dalam day to-day politik yang secara intens menumbuhkan suasana ketakutan (baik represi ideology maupun fisik) di kalangan komunitas politik yang berusaha menolak dominasi pusat. ${ }^{18}$

Mekanisme sentralistis semacam ini terus berlanjut karena disebabkan oleh dua hal. Pertama, pada tingkat nasional, elit politik pembuat keputusan tidak mempunyai basis politik lokal sama sekali, kekuatan eksekutif nasional hanyalah pada tangan Soeharto saja yang menjadi aktor tunggal dalam pentas politik nasional tidak berakar dari bawah, dan bahkan tidak membutuhkan dukungan politik dari masyarakat untuk kelangsungan kekuasaan politik mereka. Kedua, pada tingkat daerah, masyarakat politik lokal teralienasi dari mekanisme politik yang telah sepenuhnya ternasionalisasi. Bahkan juga, arena politik lokal telah dimonopoli oleh orang pusat yang ada di daerah. Oleh karena itu praktis tidak ada penolakan yang memadai dari daerah terhadap kebijakan yang sangat bisa kepentingan

${ }^{18}$ Pratikno (1999) UNISIA No.39/XXII/III, hlm. 72-73 
pusat tersebut. Dengan kata lain, secara ringkas bisa dikatakan bahwa berbagai sosok bias pusat dalam distribusi sumber daya politik dan ekonomi yang berlangsung selama 32 tahun adalah produk dari sebuah rejim, yaitu sebuah sistem politik yang otoritarian yang membangun legitimasi politiknya melalui sentralisasi serta monopoli sumber daya politik dan ekonomi secara nasional. ${ }^{19}$

\section{Politik Pasca Soeharto (Zaman Reformasi)}

Ketika pada tanggal $21 \mathrm{Mei}$ 1998 Soeharto lengser dari tampuk kepemimpinannya saat itu pulalah suatu sistem pemerintahan yang otoritarian berakhir dan naiklah Habibie ke puncak pimpinan nasional yang mau tidak mau Habibie berusaha untuk membangun pemerintahan yang legitimit melalui proses politik yang demokratis disamping menghadapi krisis ekonomi yang berkepanjangan dan berusaha juga untuk melakukan agenda-agenda reformasi. Tapi sayang sekali dalam menjalankan ini semua Habibie mengalami kesulitan, disebabkan oleh krisis legitimasi yang berimplikasi pada krisis kepercayaan. Pemerintah Habibie tidak bisa

\footnotetext{
${ }^{19} \mathrm{Ibid}, \mathrm{hlm} .73-74$
}

menunjukkan pemerintahan yang otoriter sebelumnya (Orde Baru). Di samping itu juga pemerintahan Habibie tidak bisa menciptakan citra baru bahwa pemerintahannya anti Orde Baru disebabkan Habibie sendiri tidak bisa memperkarai otoritarianisme Soeharto dan kroni -kroninya sehingga menimbulkan ketidakpercayaan masyarakat kepada pemerintahan Habibie.

Dengan munculnya krisis legitimasi dan berimbas ke krisis kepercayaan pada pemerintahan Habibie, mendorong bagi daerahdaerah untuk lebih mendesak Habibie agar lebih membuka kran demokrasi dan Hak Asasi Manusia termasuk untuk melakukan peninjauan terhadap keberadaan status Timor-Timur yang memang sudah menjadi sorotan internasional.

Akhirnya pemerintahan Habibie melaksanakan referendum di Timor - Timor dan berimplikasi bagi kemerdekaan Timor - Timor. Banyak pihak mengatakan hal ini menjadi motivasi bagi daerah-daerah yang merasa dianaktirikan dalam pembagian kue nasional untuk menuntut adanya suatu pembaharuan terhadap hubungan pusat dan daerah. Diskursus otonomi seluasluasnya, federalisme, bahkan 
merdeka nyaring terdengar di daerah-daerah yang kaya akan sumber daya alamnya seperti Aceh, Irian jaya, Riau, Ambon dan Kalimantan Timur. Pemberontakan daerah pada pasca Soeharto disebabkan oleh akumulasi ketertekanan daerah semasa Orde baru yang memang menutup rapat-rapat moneter, peradilan, pertahanan dan hubungan luar negeri. Otonomi daerah ini harus dijalankan secara konsekuen dan tidak setengah hati.

Untuk itu perlu adanya konsep baru dalam membangun hubungan karakter pusat - daerah. :

Pertama, pusat harus menghentikan kebijakan sentralistis dan keseragaman struktur administrasi di daerah dan memberikan kebijakan desentralisasi yang lebih besar kepada daerahdaerah. Oleh karena itu pengembangan desentralisasi dan otonomi daerah lebih ditekankan pada strategi dan kebijaksanaan pembangunan dan mendistribusikan bantuan pembangunan secara proporsional menurut kriteria yang rasional, sesuai kondisi, potensi serta masalah-masalah yang dihadapi daerah yang bersangkutan. Disamping itu juga memberikan ruang gerak yang lebih besar kepada daerah untuk mengambil keputusan terhadap penggunaan dana yang telah dialokasikan ke daerah.

Kedua, sistem politik nasional harus dibangun berdasarkan mekanisme demokrasi diatas pilar-pilar politik lokal yang kuat. Artinya, representasi politik tingkt nasional perlu mencerminkan perwakilan wilayah yang dipilih secara demokratis oleh rakyat daerah. Demokrasi di tingkat lokal menjadi suatu keharusan agar desentralisasi tidak membawa implikasi otoritarianisme di tingkat lokal. Pengembangan demokrasi lokal ini sekaligus untuk memindahkan orientasi politisi lokal dan ketaatan terhadap elit politik nasional kepada ketaatan kepada masyarakat daerah. ${ }^{20}$

Ketiga, otonomi yang diberikan oleh pemerintahan pusat adalah otonomi yang mandiri dalam bingkai Negara Kesatuan Republik Indonesia yang maksudnya adalah kebebasan yang dapat menjamin kemandirian dalam rangka mengembangkan kebebasan bagi daerah. Disamping itu juga disebabkan oleh ketimpangan pembangunan antara Jawa dan luar Jawa dimana Jawa terus mengalami percepatan pembangunan.
${ }_{76}^{20}$ Pratikno (1999). UNISIA. 39/XXII/III 


\begin{tabular}{lrr} 
Pemberlakuan & undang- \\
undang & Otonomi & daerah \\
pasca reformasi & sudah \\
diberlakukan tiga undang- & undang dimulai tahun 1999 \\
underan & dikeluarkannya \\
dengan & \multicolumn{2}{c}{ Undang-Undang } \\
pertama,
\end{tabular}

Nomor 22 tahun 1999 tentang otonomi daerah yang pada intinya menjelaskan bahwa sistem pemerintah Negara Kesatuan RI menurut UUD 1945 dan memberikan kekuasaan kepada daera untuk menyelenggarkan otonomi daerah. ${ }^{21}$

Kedua, pada tahun 2004 muncul UU RI no 32 tahun 2004, UU ini berisikan bahwa pemerintahan daerah mengatur dan mengurusi sendiri urusan pemerintah menurut asas otonomi dan tugas pembantuan diarahkan untuk memepercepat terwujudnya kesejahteraan masyarakat melalui peningkatan, pelayanan, pemberdayaan dan peran serta masyarakat, serta peningkatan daya saing daerah dengan memperhatikan prinsip demokrasi, pemerataan, keadilan, keistimewaan dan kekuasaan suatu daerah dalam sistem Negara Kesatuan Republik Indonenesia. ${ }^{22}$.

$$
\begin{aligned}
& \text { Ketiga, Undang-Undang } \\
& \text { nomor } 23 \text { tahun } 2014 \\
& \text { adapun dasar dikeluarkan } \\
& \text { Undang-Undang ini adalah } \\
& \text { bahwa penyelenggara } \\
& \text { pemerintah daerah diarahkan } \\
& \text { untuk mempercepat } \\
& \text { terwujudnya kesejahteraan } \\
& \text { masyarakat melalui } \\
& \text { peningkatan pelayanan, } \\
& \text { pemberdayaan dan peran } \\
& \text { serta masyarakat serta } \\
& \text { peningkatan daya saing } \\
& \text { daerah dengan } \\
& \text { memperhatikan prinsip } \\
& \text { demokrasi, pemerataan } \\
& \text { keadilan dan kekhasan } \\
& \text { daerah dalam sistem negara } \\
& \text { NKRI. }{ }^{23}
\end{aligned}
$$

\section{SOLUSI PEMECAHAN PERMASALAHAN}

Ada perbedaan yang mendasar bagi merebaknya isu federalisme di Indonesia ketika terbentuknya Republik Indonesia Serikat dan tuntutan daerah-daerah pada saat ini. Ketika pada tahun 1949 proyek federalisme memang merupakan rekayasa dari Belanda yang ingin memecah belah Indonesia dan tuntutan itu tidak berasal dari Indonesia sendiri. Pada saat ini wacana federalisme memang berasal dari tuntutan berbagai daerah di Indonesia. Ada anggapan bahwa dengan bentuk Negara Federal daerah-daerah bisa lebih mandiri dan tidak bergantung dengan pusat. Maka solusi satu-satunya adalah membentuk Negara Federasi di Indonesia.

${ }^{21}$ Lihat lebih lanjut Undang-Undang Nomor 22 tahun 1999 tentang Pemerintah Daerah.

${ }^{22}$ Lihat Undang-Undang RI Nomor 32 Tahun 2004 tentang Pemerintah Daerah

\footnotetext{
${ }^{23}$ Lihat lebih lanjut Undang-Undang RI Nomor 23
} tahun 2014 tentang Pemerintah Daerah. 
Banyak para penggagas federalism tidak mempunyai konsep yang jelas dan secara detail federalisme yang bagaimana yang akan diterapkan di Indonesia, mereka hanya membahas garis-garis besarnya saja. Sedangkan federalisme itu sendiri sangat variatif dan tidak bisa kita membuat generalisasi konsep federalisme di Indonesia melihat kondisi historis, sosial-kultur, politik, dan geografis di negara kita.

Menurut penulis sendiri dengan melihat kondisi yang objektif masingmasing daerah saat ini dan juga dari perjalanan sejarah Indonesia tawaran bentuk negara federal belum tepat untuk diterapkan dan permasalahan di Indonesia bukan terletak dari bentuk negara apakah itu Negara Kesatuan atau Negara Federasi. Solusi terbaik bagi Indonesia sendiri saat ini adalah bagaimana mengakomodasi kepentingan - kepentingan daerah dengan memberikan otonomi seluasluasnya kepada daerah dalam bentuk Negara Kesatuan Indonesia dan hanya empat hal yang bisa dilakukan oleh Pemerintah Pusat yaitu: pembangunan daerah atas dasar otoritas dan keleluasaan yang diberikan oleh pusat kepada daerah.

Agar bandul kebebasan berotonomi tidak terlepas begitu jauh mengarungi dasar negara kesatuan, diperlukan pengikat kesatuan yaitu pengawasan. Antara kemandirian otonomi dan pengawasan merupakan satu kesatuan yang tidak dapat dipisahkan. Agar otonomi tidak menciptakan suatu keadaan anarkis maka harus selalu ada cara - cara pengendalian yang menempatkan kebebasan tersebut di bawah kepentingan yang bersifat nasional. ${ }^{24}$

Keempat, semasa Orde Baru sentralisasi kekuasaan dipertahankan secara refresif oleh militer baik melalui kelembagaan-kelembagaan teritorialnya (Kodam sampai Koramil) maupun operasi-operasi tempurnya (Daerah Operasi Militer). Kini sudah saatnya mengurangi keterlibatan militer dalam pendekatan keamanan territorial dan juga fungsi militer sebaiknya diarahkan secara professional yaitu dengan menjalankan fungsi-fungsi militer tanpa memasuki lingkungan sipil.

\section{KESIMPULAN}

Munculnya berbagai tuntutan untuk meninggalkan bentuk Negara Kesatuan dan beralih kepada bentuk Negara Federal disebabkan reaksi sentralisme yang berlebihan dan adanya ketimpangan penbangunan antara Jawa dan luar Jawa semasa Orde Lama dan Orde baru. Ketika angin reformasi bergulir saat itulah berbagai daerah semakin keras untuk menuntut kemandirian daerah bahkan sampai menuntut pembentukan negara federal dan yang lebih berbahaya lagi sebagian daerah ingin membentuk negara sendiri.

Untuk menentukan Indonesia memilih bentuk negara federasi tidaklah semudah dibayangkan, karena banyak berbagai hal yang memang harus dipertimbangkan

${ }^{24}$ Willian O Hat (Et.Al). Introduction to the Law of Local Government and Administration. Butterworths. London 1973. Lihat Juga Bagir Manan, "Politik Hukum Otonomi Daerah Sepanjang Peraturan Perundang-undangan Pemerintah Daerah" Makalah Dalam Seminar Nasional. 
terutama ketika kita mencoba menelaah kembali kepada proses pembentukan republik ini. Dimana para founding father kita telah bersepakat membentuk Negara Kesatuan. Disamping itu proses perjalanan sejarah telah membuktikan bahwa proyek federalisme tidak relevan bagi sosial budaya Indonesia.

Sebenarnya bagi penulis sendiri permasalahan bukan terletak bahwa kita harus memilih negara federasi dalam menghadapi gejolak-gejolak yang terjadi di daerah saat ini. Karena apapun bentuk negara kalau pemerintah sendiri tidak mempunyai kemauan untuk memberi kemandirian yang luas pada daerah, maka tidak ada artinya proyek federalisme yang dilontarkan oleh beberapa penggagasnya. Saatnya pemerintah mulai melaksanakan politik akomodatif untuk menciptakan hubungan antara pemerintah pusat dan pemerintah daerah secara proporsional dan menciptakan kemandirian daerah dalam mengurus rumah tangganya sendiri.

\section{DAFTAR PUSTAKA}

Andi A. Mallarangeng \& M. Ryaas Rasyid, (1999) Otonomi dan Federalisme dalam buku Federalisme Untuk Indonesia, Jakarta : Penerbit Kompas.

Bagir Manan, "Politik Hukum Otonomi Daerah Sepanjang Peraturan Perundangundangan Pemerintah Daerah" Makalah Dalam Seminar Nasional.

Harun Al Rasyid. (1999). Federalisme Mungkinkah bagi Indonesia dalam buku Fedelisme Untuk Indonesia. Jakarta : Penerbit Kompas
Haw. Widjaja, Penyelenggaraan Otonomi Daerah, (2013), Jakarta, Rajawali Press.

Ichlasul Amal (1992) Regional and Central Government in Indonesia Politics : West Sumatra And South Sulawesi 1949 1979. Yogyakarta Gajah Mada University Press.

Jimly Asshiddiqie, (2007), Pokok-Pokok Hukum Tata Negara Indonesia Pasca Reformasi, Jakarta, Buana Ilmu Populer..

Joseph Rudolph., Jr "Federation". Dalam International Encyclopedia of Government and Politics. Vol. 1 yang diedit Frank N. Magill. Singapura : Toppan 1996, hlm. 467.

M. Solly Lubis. (1983). Pergeseran Garis Politik dan Perundang-Undangan Mengenai Pemerintah Daerah. Bandung : Alumni.

Miriam Budiardjo, (2008), Dasar-Dasar Ilmu Politik, Jakarta Gramedia Pustaka Utama.

Moh. Kusnardi, Bintan R Saragih (2008), Ilmu Negara, Jakarta, Gaya Media Pratama.

Pratikno, (1999), Unisia No 39/XXII/III

Syamsul Rizal Panggabean. "Komparasi Konsep Bentuk Negara Kesatuan dan Negara Federasi Dalam Pembangunan Politik di Indonesia. "Makalah disampaikan pada Seminar Nasional Membangun Indonesia Baru: Suatu Pendekatan Konstitusional dan politik. Diselenggarakan atas kerjasama FHUGM, KHRN, LBKHI, dan Augustinus Hutajulu, SH, CN \& Associate, Yogyakarta. 31 Oktober 1998 
Willian O Hat (Et.Al). Introduction to

the Law of Local Government and Administration. Butterworths. London 1973.

Undang-Undang RI Nomor 22 Tahun 1999 tentang Pemerintah Daerah.

Undang-Undang RI Nomor 32 Tahun 2004 tentang Pemerintah Daerah.

Undang-Undang RI Nomor 32 Tahun 2014 tentang Pemerintah Daerah

Blogspot.com/2014/05/ UU mengenai otonomi daerah yang pernah berlaku di Indonesia serta perbandingannya

II. S

O

L

U

S

I

P

E

M

E

C

A

H

A

$\mathbf{N}$

P

E

R

M

A

S

A

L

A

H

A 